\title{
Filigrane
}

Écoutes psychothérapiques

\section{Filigrane a reçu pour vous}

\section{Hélène Richard}

Volume 16, numéro 2, automne 2007

Les hauts lieux et non-lieux du rêve II

URI : https://id.erudit.org/iderudit/016926ar

DOI : https://doi.org/10.7202/016926ar

Aller au sommaire du numéro

Éditeur(s)

Revue Santé mentale au Québec

ISSN

1192-1412 (imprimé)

1911-4656 (numérique)

Découvrir la revue

Citer ce document

Richard, H. (2007). Filigrane a reçu pour vous. Filigrane, 16(2), 111-111.

https://doi.org/10.7202/016926ar d'utilisation que vous pouvez consulter en ligne.

https://apropos.erudit.org/fr/usagers/politique-dutilisation/ 


\section{Filigrane a reçu pour vous}

\section{hélène richard}

Le Coq-héron, dossier «Nos rêves: entre leurs myceliums, leurs chrysalides et leurs destins », $\mathrm{n}^{\circ}$ 191, automne 2007 